\title{
Production of ethanol from mesquite (Prosopis juliflora (SW) D.C.) pods mash by Zymomonas mobilis and Saccharomyces cerevisiae
}

\author{
Celiane Gomes Maia da Silva ${ }^{1}$ Tânia Lúcia Montenegro Stamford ${ }^{2}$ \\ Samara Alvachian Cardoso de Andrade ${ }^{3}$ Evandro Leite de Souza ${ }^{4} \varangle$ \\ Janete Magali de Araújo ${ }^{5}$ \\ 1 Departamento de Ciências Domésticas, Universidade Federal Rural de Pernambuco, Pernambuco, Recife, \\ Brasil \\ 2 Departamento de Nutrição, Universidade Federal de Pernambuco, Pernambuco, Recife, Brasil \\ 3 Departamento de Engenharia Química, Universidade Federal de Pernambuco, Pernambuco, Recife, Brasil \\ 4 Departamento de Nutrição, Centro de Ciências da Saúde, Universidade Federal da Paraíba, João Pessoa, \\ Paraíba, Brasil \\ 5 Departamento de Antibióticos, Centro de Ciências Biológicas, Universidade Federal de Pernambuco, \\ Pernambuco, Recife, Brasil
}

$\triangle$ Corresponding author: evandroleitesouza@ccs.ufpb.br

Received June 2, 2009 / Accepted July 29, 2010

Published online: September 15, 2010

(c) 2010 by Pontificia Universidad Católica de Valparaíso, Chile

\begin{abstract}
This study aimed to assess the use of mesquite pods hydrated mash as biomass for the growth of Saccharomyces cerevisiae UFEPEDA-1012 and Zymomonas mobilis UFEPEDA-205 and for ethanol production using a submerged fermentation. A $2^{3}$ factorial design was used to analyze the effects of the type of microorganism, time of fermentation and condition of cultivation on the ethanol

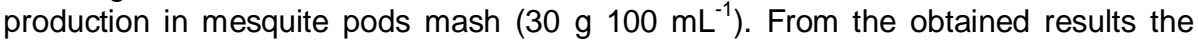
hydrated mesquite pods mash presented as a good substrate for the growth of $S$. cerevisiae and $Z$. mobilis in comparison to the standard media. The effect that most affected the ethanol production was the type of microorganism. The highest ethanol concentration (141.1 $\mathrm{gL}^{-1}$ ) was found when $Z$. mobilis was cultivated in mesquite pods mash under static condition for $36 \mathrm{hrs}$. Ethanol production by S. cerevisiae was higher $\left(44.32 \mathrm{gL}^{-1}\right)$ after $18 \mathrm{hrs}$ of fermentation under static condition. According to these results, the mesquite pods could be known as an alternative substrate to be used for biotechnological purposes, mainly for ethanol production.
\end{abstract}

Keywords: ethanol, mesquite, Saccharomyces cerevisiae, Zymomonas mobilis 
da Silva et al.

\section{INTRODUCTION}

With the inevitable depletion of the world's petroleum supply, there has been an increasing worldwide interest in alternative, non-petroleum-based sources of energy. A growing, yet controversial, source of transportation fuel is fermentation-derived ethanol whose production cost still requires significant government subsidy to permit producers to remain in business (Montesinos and Navarro, 2000; Palmarola-Adrados et al. 2005). However, in the future, with the increased growth of energy crops and economies of scale, cost reduction may make biofuels competitive in their own right (Narendranath and Power, 2004; Gray et al. 2006).

Nearly all fuel ethanol is produced by fermentation of corn glucose in the United States or sugar cane sucrose in Brazil (Rosillo-Calle and Cortez, 1998), but any country with a significant agronomic-based economy can use current technology for fuel ethanol production (Mielenz, 2001; Atiyeh and Duvnjak, 2002; Bothast and Schleicher, 2005).

During the last two decades, technology for ethanol production from non-food-plant sources has been developed to the point at which large-scale production could be a reality in the next few years (Montesinos and Navarro, 2000). Moreover, agronomic residues such as corn stover (corn cobs and stalks), sugar cane waste, wheat or rice straw, forestry and paper mill discards, the paper potion of municipal waste, and mainly dedicated energy crops - collectively termed 'biomass'- can be converted to fuel ethanol (Datar et al. 2004).

Prosopis juliflora ((SW) D.C.), Leguminosae, popularly known as mesquite, is native to Central and South America and has spread to North America. Mesquite had been introduced to many arid zone countries, with rainfall of less than $200 \mathrm{~mm} / \mathrm{year}$, to combat desertification as it is an $\mathrm{N}$-fixing legume and livestock consume its pods (Tabosa et al. 2000; Araújo et al. 2002; Mahgoub et al. 2005). Mesquite shows great potential for use as a multipurpose tree in different parts of the world, in comparison to several native and exotic species (Kailappan et al. 2000; Deans et al. 2003).

Table 1. Factorial design $2^{3}$ for studies of the factors time of fermentation, type of microorganism and fermentation condition.

\begin{tabular}{|c|c|c|c|c|c|c|}
\hline \multirow[t]{2}{*}{$\begin{array}{l}\text { Experimental } \\
\text { run }\end{array}$} & \multicolumn{3}{|c|}{$\begin{array}{c}\text { Codified } \\
\text { variables } \\
\end{array}$} & \multicolumn{3}{|c|}{ No codified variables } \\
\hline & $\mathrm{X}_{1}$ & $\mathrm{X}_{2}$ & $\mathrm{X}_{3}$ & $\begin{array}{l}\text { Time of } \\
\text { fermentation } \\
\text { (hrs) }\end{array}$ & $\begin{array}{l}\text { Type of } \\
\text { microorganism }\end{array}$ & $\begin{array}{l}\text { Condition of } \\
\text { fermentation }\end{array}$ \\
\hline 1 & -1 & -1 & -1 & 18 & S. cerevisiae & Static \\
\hline 2 & 1 & -1 & -1 & 36 & S. cerevisiae & Static \\
\hline 3 & -1 & 1 & -1 & 18 & Z. mobilis & Static \\
\hline 4 & 1 & 1 & -1 & 36 & Z. mobilis & Static \\
\hline 5 & -1 & -1 & 1 & 18 & S. cerevisiae & Stirring \\
\hline 6 & 1 & -1 & 1 & 36 & S. cerevisiae & Stirring \\
\hline 7 & -1 & 1 & 1 & 18 & Z. mobilis & Stirring \\
\hline 8 & 1 & 1 & 1 & 36 & Z. mobilis & Stirring \\
\hline
\end{tabular}


Mesquite pods are a significant feed source for livestock in many areas of the world (Batista et al. 2002). Pod production per tree can vary from a few $\mathrm{kg}$ to over $400 \mathrm{~kg}$ and is highly dependent on moisture availability to the plant. The mesquite pods production is of approximately 10 tons per hectare of planted tree. In the northeast region of Brazil, mesquite trees cover 150.000 hectares (Riveros, 1992).

Zymomonas mobilis has been considered a promising alternative to Saccharomyces cerevisiae in the synthesis of ethanol. Comparative with yeast, $Z$. mobilis has a higher tolerance to ethanol and better kinetic characteristics such as higher specific substrate uptake, ethanol synthesis rate and substrate yield to ethanol. Moreover, it has advantages for the fermentation of glucose to ethanol which include a high yield of ethanol from glucose consumed and a high specific rate of ethanol production (Joachimsthal et al. 1998; Tano and Buzato, 2003).

Table 2. Determination of glucose, total proteins and $\mathrm{pH}$ in liquefied mash prepared with different concentration of ground mesquite.

\begin{tabular}{|c|c|c|c|}
\hline $\begin{array}{l}\text { Mesquite concentration } \\
\left(\mathrm{g} 100 \mathrm{~mL}^{-1}\right)\end{array}$ & $\begin{array}{l}\text { Total sugar* } \\
\left(g L^{-1}\right)\end{array}$ & $\begin{array}{l}\text { Glucose } \\
\left(g^{-1}\right)\end{array}$ & $\begin{array}{l}\text { Total proteins } \\
\left(g^{-1}\right)\end{array}$ \\
\hline 10 & $3.83 \pm 0.04^{\mathrm{d}}$ & $1.29 \pm 0.01^{\mathrm{d}}$ & $5.90 \pm 0.28^{e}$ \\
\hline 15 & $5.75 \pm 0.01^{c}$ & $2.21 \pm 0.03^{c}$ & $10.40 \pm 1.41^{d}$ \\
\hline 20 & $7.67 \pm 0.07^{c}$ & $2.29 \pm 0.06^{c}$ & $11.35 \pm 1.48^{\mathrm{cd}}$ \\
\hline 25 & $9.58 \pm 0.02^{b}$ & $3.46 \pm 0.01^{b}$ & $14.95 \pm 1.34^{b c}$ \\
\hline 30 & $11.50 \pm 0.06^{\mathrm{a}}$ & $3.99 \pm 0.38^{a}$ & $17.70 \pm 1.13^{\mathrm{ab}}$ \\
\hline 35 & $13.40 \pm 0.08^{a}$ & $3.98 \pm 0.10^{a}$ & $18.85 \pm 0.92^{\mathrm{ab}}$ \\
\hline 40 & $15.30 \pm 0.05^{a b}$ & $3.79 \pm 0.07^{\mathrm{ab}}$ & $18.10 \pm 2.97^{a b}$ \\
\hline 45 & $13.40 \pm 0.01^{\mathrm{a}}$ & $3.88 \pm 0.03^{a}$ & $19.80 \pm 2.45^{\mathrm{a}}$ \\
\hline
\end{tabular}

Regarding the high amount of carbohydrates present in mesquite pods (Bravo et al. 1994) and their high production in different countries, they could arise as a feasible alternative source for ethanol production. In this study the use of mesquite pods hydrated mash was assessed as biomass for the growth of Saccharomyces cerevisiae UFEPEDA-1012 and Zymomonas mobilis UFEPEDA-205 and also for production of ethanol by submerged fermentation. Moreover, an analysis of main effects was carried out in order to identify the best conditions for the ethanol production regarding the type of microorganism, condition of fermentation and the time of fermentation. To our knowledge there is a lack of studies about the ethanol production by $S$. cerevisiae and $Z$. mobilis using mesquite pods mash as fermentable substrate.

\section{MATERIALS AND METHODS}

\section{Microorganisms}

Strains of S. cerevisiae UFEPEDA-1012 and Z. mobilis UFEPEDA-205 used in this study were gently supplied by the Microorganisms Collection, Department of Antibiotics, Federal University of Pernambuco, Recife, Brazil. Stock cultures of $S$. cerevisiae and Z. mobilis were kept in Standard Swings \& De Ley - SSDL agar 
(glucose 20.0; yeast extract 5.0; agar $15 \mathrm{gL}^{-1}$ ) (Swings and De Ley, 1977) and Sabouraud agar (peptone 10.0; glucose 20; agar $17 \mathrm{gL}^{-1}$ ) slants, respectively, under refrigeration.

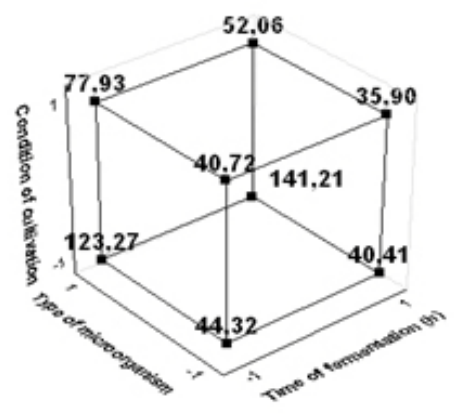

a. Ethanol $\left(\mathrm{gL}^{-1}\right)$

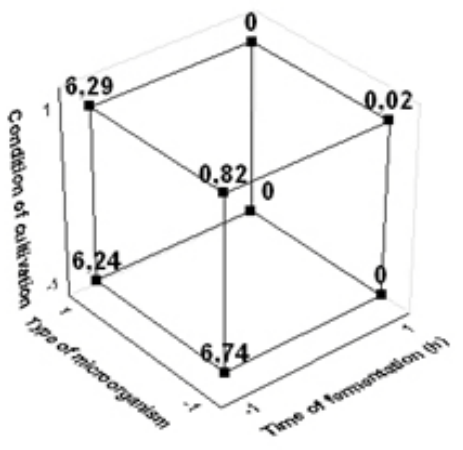

b. Glucose $\left(\mathrm{gL}^{-1}\right)$

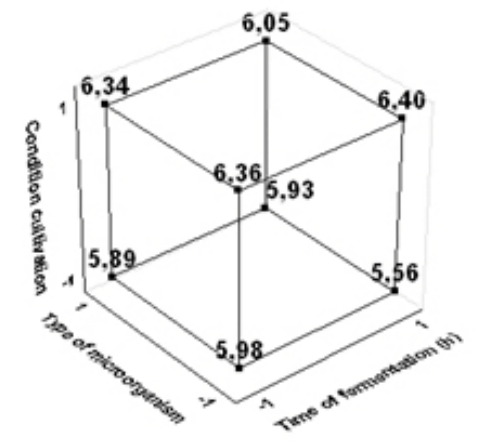

c. Microbial count (Log cfu mL $\left.{ }^{-1}\right)$

Fig. 1 Effects of the interaction of time of fermentation, type of microorganism and condition of cultivation on the ethanol production.

(a) Ethanol.

(b) Glucose.

(c) Microbial count. 
For experimental assays, S. cerevisiae and Z. mobilis were grown in $50 \mathrm{~mL}$ of Sabouraud broth at $28^{\circ} \mathrm{C}$ and SSDL broth at $37^{\circ} \mathrm{C}$, respectively. After the $48 \mathrm{hrS}$ incubation, $5 \mathrm{~mL}$ of the culture was added to flasks containing $95 \mathrm{~mL}$ of the same growth media and allowed to grow at room temperature for 24 hrs under stirring (150 rpm).

\section{Preparation of hydrated mesquite mash}

Liquefied mash was prepared using healthy mesquite pods gently supplied by SUPRANOR (Suprimentos de Alimentos do Nordeste S/A, Rio Grande do Norte, Brazil). Pods were dried at $45^{\circ} \mathrm{C}$ for $18 \mathrm{hrs}$, followed for grounding in hammer mill with a \#4 screen to get the appropriate grind size. Mesquite pods ground presented moisture 5.8; total sugars 56.5; reducing sugars (glucose) 4.6; total fiber 7.2; total proteins 9.0; fat 2.1; and axes $0.2 \mathrm{~g} 100 \mathrm{~g}^{-1}$ (Silva et al. 2007). Hydrated mash was prepared using different concentrations of ground mesquite pods $(10 ; 15 ; 20 ; 25 ; 30$;

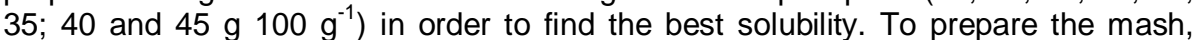
ground mesquite was slowly added to distilled water in a constant agitation. After the addition of the proper ground amount, the mash was heated to $50^{\circ} \mathrm{C}$, maintained at this temperature for $1 \mathrm{hr}$ and submitted to centrifugation (3000 rpm for $15 \mathrm{~min}$ ). The supernatant was vacuumed filtered using Whatman no. 1 and autoclaved at $121^{\circ} \mathrm{C}$ for 15 min. The mash was cooled to room temperature and aliquots were aseptically dispensed in sterile Erlenmeyer flasks for fermentation.

Mashes at different concentrations (10-45 g $100 \mathrm{~mL}^{-1}$ ) of mesquite pods ground were analyzed for total sugar $\left(\mathrm{gL}^{-1}\right)$ according to Instituto Adolfo Lutz (IAL, 2005), glucose $\left(\mathrm{gL}^{-1}\right)$ using the kit Glicose PAP - Liquiform (Labtest Diagnóstica, Minas Gerais, Brazil); total proteins $\left(\mathrm{gL}^{-1}\right)$ using the kit Total Proteins (Labtest Diagnóstica, Minas Gerais, Brazil); pH using a Micronal B474 pHmeter; and for total soluble solids using a refractometer (Shibuya Optical Co. Ltda, Japan). The mash at $30 \mathrm{~g} \mathrm{~mL}^{-1}$ was also analyzed for total sugar, reducing sugar (sucrose), proteins, total fiber, ashes, fat and tannin according to procedures described by Instituto Adolfo Lutz (IAL, 2005).

\section{Growth kinetics}

The growth of S. cerevisiae UFEPEDA-1012 and Z. mobilis UFEPEDA-205 was evaluated in mesquite hydrated mash (added of $\left(\mathrm{NH}_{4}\right)_{2} \mathrm{SO}_{4} 0.1 \mathrm{~g} 00 \mathrm{~g}^{-1}$ and $\mathrm{KH}_{2} \mathrm{PO}_{4}$ $0.2 \mathrm{~g} 100 \mathrm{~g} \mathrm{~g}^{-1}$ ) and in standard broth. Sabouraud broth was used as standard broth for S. cerevisiae, while for Z. mobilis it was SSDL. For this, a $5 \mathrm{~mL}$ of a $24 \mathrm{hrs}$ old culture was added to $95 \mathrm{~mL}$ of the growth medium and incubated at room temperature under static and stirring (150 rpm) condition. At 0, 2, 4, 6, 8, 10, 12, 14, 16, 18, 20 and 24 hrs post incubation a $100 \mu \mathrm{L}$ aliquot of the mixture was uniformly spread on sterile Sabouraud and SSDL agar Petri dishes at $28^{\circ} \mathrm{C}$ and $37^{\circ} \mathrm{C}$ for S. cerevisiae and $Z$. mobilis, respectively. Each experiment was made in triplicate and the results were expressed in Log of Colony Forming Units per $\mathrm{mL}^{(\text {Log cfu mL}} \mathrm{m}^{-1}$ ). 
Table 3. Physico-chemical variables of mesquite hydrated mash at $30 \mathrm{~g} \mathrm{~mL}^{-1}$.

\begin{tabular}{cc}
\hline Physico-chemical variables & Amount $\mathbf{~ g L ~}^{\mathbf{- 1}} \mathbf{)}$ \\
\hline Total sugars* & $16.1 \pm 0.4$ \\
Reducing sugar (glucose) & $3.99 \pm 0.3$ \\
Proteins & $2.16 \pm 0.5$ \\
Total fiber & $3.99 \pm 0.38$ \\
Ashes & $1.80 \pm 0.1$ \\
Fat & $0.63 \pm 1.3$ \\
Tanin & $0.09 \pm 0.0$ \\
Brix & $18 \pm 0.01$ \\
\hline
\end{tabular}

* sucrose

\section{Conditions of fermentation}

Submerged fermentation of mesquite hydrated mash by $S$. cerevisiae UFEPEDA1012 and Z. mobilis UFEPEDA-205 was analyzed. Mesquite mash (added of $\left(\mathrm{NH}_{4}\right)_{2} \mathrm{SO}_{4} 0.1 \mathrm{~g} 100 \mathrm{~g}^{-1}$ and $\mathrm{KH}_{2} \mathrm{PO}_{4} 0.2 \mathrm{~g}^{2} 00 \mathrm{~g} \mathrm{~g}^{-1}$ ) was aseptically distributed in

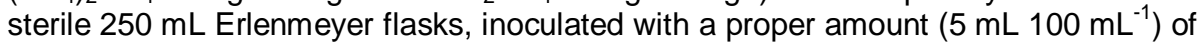
a $24 \mathrm{hrs}$ old culture and incubated at room temperature under static or stirring (150 rpm) condition. At 18 and 36 hrs of fermentation, samples were withdrawn and analyzed for ethanol concentration, $\mathrm{pH}$ value and microbial growth. $\mathrm{pH}$ and microbial growth analysis were carried out as before cited, and the ethanol concentration was determined using Gas Chromatography (GC).

\section{GC analysis}

Concentration of ethanol was determined using a gas chromatograph (HP 5890, Hewlett-Packard, Palo Alto, CA) fitted to a flame ionizer detector. A $2 \mu \mathrm{L}$-portion of the fermentation sample was injected onto a column $(30 \mathrm{~m} ; 0.25 \mathrm{~mm}$ inner diameter; 0.25 Im, J\&W Scientific, Folsom, CA). The chromatographic conditions were as follow: sample (without dilution) injection volume $2 \mu \mathrm{L}$; hydrogen flow rate $5.0 \mathrm{~mL} \mathrm{~min}{ }^{-1}$; temperature program $120^{\circ} \mathrm{C}$ (isotherm); injector temperature $100^{\circ} \mathrm{C}$; detector temperature $120^{\circ} \mathrm{C}$. The data were processed using the Millennium Computer Program (Waters Chromatograph Division, Milford, MA, USA).

\section{Experimental design $\left(2^{3}\right)$}

A 2 (times of fermentation: 18 and 36 hrs) $\times 2$ (types of microorganism: S. cerevisiae and $Z$. mobilis) $\times 2$ (conditions of fermentation: static and stirring) was carried out to optimize the fermentation process. This design provided eight assays (Table 1) which were repeated three times. The observed answers were ethanol concentration $\left(\mathrm{gL}^{-1}\right)$, glucose concentration $\left(\mathrm{gL}^{-1}\right)$ and microbial count $\left(\log \mathrm{cfu} \mathrm{mL} \mathrm{m}^{-1}\right)$ after 18 and $36 \mathrm{hrs}$ of fermentation. 
Table 4. Count (log cfu $\mathrm{mL}^{-1}$ ) of $S$. cerevisiae in Sabouraud broth and mesquite liquefied mash during $24 \mathrm{hrs}$ under static and stirring condition.

\begin{tabular}{ccccc}
\hline \multirow{2}{*}{$\begin{array}{c}\text { Time } \\
\text { (hrs) }\end{array}$} & \multicolumn{2}{c}{ Sabouraud broth } & \multicolumn{2}{c}{ Mesquite hydrated mash } \\
\cline { 2 - 5 } & Stirring & Static & Stirring & Static \\
0 & $5.00 \pm 0.11^{\mathrm{Aa}}$ & $4.98 \pm 0.00^{\mathrm{Aa}}$ & $5.03 \pm 0.07^{\mathrm{Aa}}$ & $4.97 \pm 0.01^{\mathrm{Aa}}$ \\
\hline 2 & $5.10 \pm 0.03^{\mathrm{Aa}}$ & $4.72 \pm 0.07^{\mathrm{Ab}}$ & $5.13 \pm 0.03^{\mathrm{Aa}}$ & $4.87 \pm 0.11^{\mathrm{Aa}}$ \\
\hline 4 & $4.98 \pm 0.23^{\mathrm{Aa}}$ & $4.79 \pm 0.05^{\mathrm{Ba}}$ & $5.42 \pm 0.06^{\mathrm{Aa}}$ & $5.29 \pm 0.15^{\mathrm{Aa}}$ \\
\hline 6 & $4.20 \pm 0.30^{\mathrm{Ba}}$ & $4.85 \pm 0.03^{\mathrm{Ba}}$ & $5.69 \pm 0.12^{\mathrm{Aa}}$ & $5.06 \pm 0.01^{\mathrm{Ab}}$ \\
\hline 8 & $5.20 \pm 0.02^{\mathrm{Ba}}$ & $4.83 \pm 0.01^{\mathrm{Bb}}$ & $5.98 \pm 0.06^{\mathrm{Aa}}$ & $5.31 \pm 0.07^{\mathrm{Ab}}$ \\
\hline 10 & $5.40 \pm 0.03^{\mathrm{Ba}}$ & $4.87 \pm 0.05^{\mathrm{Bb}}$ & $6.08 \pm 0.03^{\mathrm{Aa}}$ & $5.66 \pm 0.08^{\mathrm{Ab}}$ \\
\hline 12 & $6.04 \pm 0.05^{\mathrm{Ba}}$ & $5.55 \pm 0.11^{\mathrm{Ab}}$ & $6.35 \pm 0.03^{\mathrm{Aa}}$ & $5.68 \pm 0.06^{\mathrm{Ab}}$ \\
\hline 14 & $6.03 \pm 0.06^{\mathrm{Ba}}$ & $5.02 \pm 0.08^{\mathrm{Bb}}$ & $6.37 \pm 0.02^{\mathrm{Aa}}$ & $5.70 \pm 0.03^{\mathrm{Ab}}$ \\
\hline 16 & $6.14 \pm 0.03^{\mathrm{Ba}}$ & $5.45 \pm 0.03^{\mathrm{Bb}}$ & $6.34 \pm 0.01^{\mathrm{Aa}}$ & $5.71 \pm 0.03^{\mathrm{Ab}}$ \\
\hline 18 & $5.79 \pm 0.01^{\mathrm{Ba}}$ & $5.22 \pm 0.06^{\mathrm{Bb}}$ & $6.36 \pm 0.01^{\mathrm{Aa}}$ & $5.92 \pm 0.06^{\mathrm{Ab}}$ \\
\hline 20 & $5.97 \pm 0.01^{\mathrm{Ba}}$ & $5.22 \pm 0.06^{\mathrm{Bb}}$ & $6.14 \pm 0.05^{\mathrm{Aa}}$ & $5.89 \pm 0.04^{\mathrm{Ab}}$ \\
\hline 22 & $5.88 \pm 0.02^{\mathrm{Ba}}$ & $5.23 \pm 0.04^{\mathrm{Bb}}$ & $6.28 \pm 0.06^{\mathrm{Aa}}$ & $5.64 \pm 0.03^{\mathrm{Ab}}$ \\
\hline 24 & $6.17 \pm 0.07^{\mathrm{Aa}}$ & $5.74 \pm 0.06^{\mathrm{Ab}}$ & $6.11 \pm 0.11^{\mathrm{Aa}}$ & $5.40 \pm 0.01^{\mathrm{Bb}}$ \\
\hline
\end{tabular}

a average with different caption letters at the same column significantly differ $(p<0.05)$ according to the Student T test.

${ }^{b}$ average with different small letters at the same line for each growth medium significantly differ $(p<0.05)$ according to the Student $\mathrm{T}$ test.

\section{Statistical analysis}

Data of microbial counts were evaluated for significant difference $(p<0.05)$ by Student t test. Data of total proteins, $\mathrm{pH}$, sucrose and glucose were evaluated for significant difference $(p<0.05)$ by Duncan test. The answers obtained in the $2^{3}$ factorial design were evaluated for main effects and their interaction. All statistical analyses were carried out using the software Statistica 6.0.

\section{RESULTS AND DISCUSSION}

\section{Preparation of the fermentable substrate}

Different concentrations (10-45 g $100 \mathrm{~mL}^{-1}$ ) of mesquite pods ground were evaluated for best preparation of the fermentable substrate regarding the maximum solubility. For this, the concentration of glucose, sucrose, total proteins, total soluble solids in the mash prepared with different concentrations of ground mesquite were assessed (Table 2). The amount of sucrose, glucose and total proteins found for the mashes showed no significant difference $(p>0.05)$ as the amount of mesquite ground was 30 $\mathrm{g} 100 \mathrm{~mL}^{-1}$ or more. It suggests a possible saturation of these compounds (resulting in 


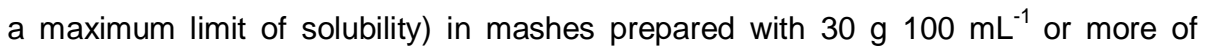
ground.

No range was found for $\mathrm{pH}$ at the different mashes (data not showed). $\mathrm{pH}$ values (5.4$5.5)$ found for the mashes are considered as appropriate for fermentation (Mclellan et al. 1999).

Regarding these findings the mash prepared with $30 \mathrm{~g} 100 \mathrm{~mL}^{-1}$ of mesquite pods ground was chosen to be included in the assays for microbial growth and ethanol production. The physico-chemical variables of mesquite hydrate mash at $30 \mathrm{~g} \mathrm{~mL}^{-1}$

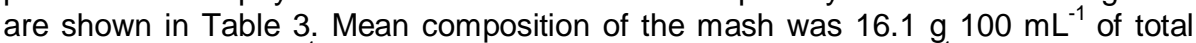

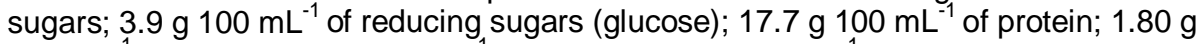

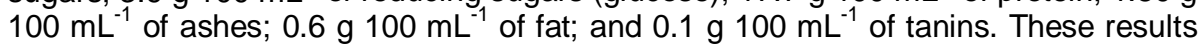
are in accordance with previous studies showing the high availability of fermentable sugars in mesquite mash besides a small amount of the phenolic tannin. It was found a total soluble solids value of $18^{\circ} \mathrm{Bx}$. For sugar cane juice an amount of total soluble solids in a range of $12-18^{\circ} \mathrm{Bx}$ (g sucrose $100 \mathrm{~g} \mathrm{juice}^{-1}$ ) is regarded suitable for ethanol production (Tano and Buzato, 2003).

\section{Microbial growth}

The results of the growth kinetic of S. cerevisiae UFPEDA-1012 in Sabouraud broth and mesquite hydrated mash along $24 \mathrm{hrs}$ in static and stirring cultivation are shown in Table 4. Counts of $S$. cerevisiae in Sabouraud broth obtained for static and stirring cultivation from 8 hrs onwards significantly differed $(p<0.05)$. When growing in mesquite hydrated mash significant differences were found from $6 \mathrm{hrs}$ onwards. Counts of S. cerevisiae were always higher in mesquite mash along the $24 \mathrm{hrs}$ of incubation.

Highest counts of S. cerevisiae $\left(>6 \log \mathrm{cfu} \mathrm{mL} \mathrm{m}^{-1}\right.$ ) in both assayed growth media were found in stirring cultivation. This phenomenon (named Pasteur Effect) is commonly found in Saccharomyces genus, where the yeast growth best in aerobic atmosphere resulting in a fast sugar consumption (Carvalho et al. 2006). The decrease in the counts of S. cerevisiae at 18 to $22 \mathrm{hrs}$ of incubation could be possibly related to a metabolic repression (or enzymatic repression) resulting in a smaller microbial growth rate. Metabolic repression in some microorganisms occurs when high glucose

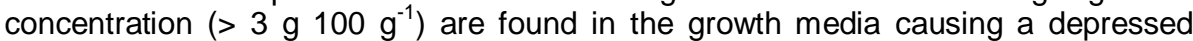
synthesis of respiratory/oxidative enzymes and ultimately resulting an increasing fermentative metabolism even when oxygen is available (Atiyeh and Duvnjak, 2002; Mahgoub et al. 2005).

The results of the growth kinetic of Z. mobilis UFEPEDA-205 in SSDL broth and mesquite hydrated mash along 24 hrs under static and stirring condition are shown in Table 5. Counts of $Z$. mobilis in SSDL broth obtained for static and stirring cultivation were significantly different $(p<0.05)$ from $10 \mathrm{hrs}$ onwards. Highest counts of $Z$.

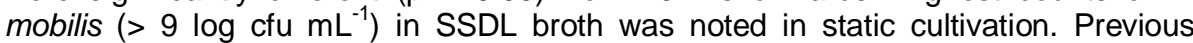
studies found higher counts of $Z$. mobilis under anaerobic condition in comparison to aerobic one (Bringer et al. 1984; McLellan et al. 1999). It is reported that the extremely effective action of oxygen as electron acceptor could provide a disturbance in biosynthesis metabolic reactions of different microorganisms causing a decreased specific growth rate (O'Brien and Morris, 1971). 
Z. mobilis presented higher counts when growing in SSDL in comparison to mesquite mash. Significant differences $(p<0.05)$ between the counts of $Z$. mobilis found in mesquite mash incubated under static and stirring condition were only noted from 18 hrs of cultivation on.

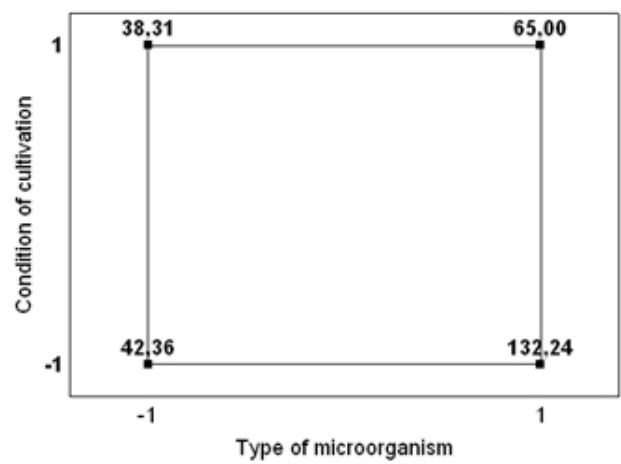

Fig. 2 Effects of the interaction of type of microorganism and condition of cultivation on the ethanol production $\left(\mathrm{gL}^{-1}\right)$ in hydrated mesquite mash.

Along $24 \mathrm{hrs}$ of fermentation the $\mathrm{pH}$ values of the growth media were in a range of 4.8-5.2 (data not showed). Bacterial contamination (mainly by Lactobacillus) in an industrial-scale ethanol production is the major cause for reduced ethanol yield. Sharply changes in $\mathrm{pH}$ of fermentable substrates could indicate the presence of contaminating bacteria in high amounts during the fermentation process (Mielenz, 2001).

\section{Factorial design}

Results of the analysis of main effects and their interaction in the $2^{3}$ factorial design for ethanol production in mesquite hydrated mash by submerged fermentation are showed in Table 6. From the obtained results the effect that most affected (58.28) the ethanol production was the type of microorganism $\left(X_{2}\right)$. The highest ethanol concentration (141.1 $\mathrm{gL}^{-1}$ ) was found in the levels 1 (36 hrs), 1 (Z. mobilis) and -1 (static cultivation). Ethanol production by $S$. cerevisiae was higher $\left(44.32 \mathrm{gL}^{-1}\right)$ after $18 \mathrm{hrs}$ of fermentation under static condition (Figure 1a).

The highest ethanol concentration $\left(77.93 \mathrm{gL}^{-1}\right)$ in stirring cultivation was noted for levels -1 (18 hrs) and 1 (Z. mobilis) in $X_{1} X_{2}$ (Figure 1a). This ethanol amount is higher than that $\left(23.34 \mathrm{gL}^{-1}\right)$ found by Borsari et al. (2006) when $Z$. mobilis was inoculated in sugar cane juice for $20 \mathrm{hrs}$ under stirring. Shene and Bravo (2001) studying the ethanol production by $Z$. mobilis in a mixture of glucose-fructose under static cultivation noted a highest concentration of ethanol $\left(40 \mathrm{gL}^{-1}\right)$ after $24 \mathrm{hrs}$ of fermentation. According to our results, Z. mobilis when growing in mesquite mash under static condition produced higher amounts of ethanol in comparison to the findings of these researchers.

Time of fermentation $\left(X_{1}\right)$ was the effect that most negatively affected $(-5.02)$ the glucose concentration in the mash (Table 6 and Figure 1b). These results suggest 
that up to $36 \mathrm{hrs}$ of fermentation the glucose dispersed in the base media was totally metabolized for ethanol production. Z. mobilis presents a prominent capacity of hydrolyzing the sucrose dispersed in a growth media and rapidly metabolize fructose and glucose as carbon source for the ethanol production by the Entner-Doudoroff way (Swings and De Ley, 1977). According to Favela Torres and Baratti (1988) the availability of glucose, fructose or sucrose in the growth media increases the ethanol yield by $Z$. mobilis. On the other hand, small yields of ethanol are found in substrates with high amount of cellulose, inulin or starch since the bacteria is not able to hydrolyze these polymers (Swings and De Ley, 1977).

Table 5. Count $\left(\log \mathrm{cfu} \mathrm{mL}^{-1}\right)$ of $Z$. mobilis in SSDL broth and mesquite liquefied mash during $24 \mathrm{hrs}$ under static and stirring condition.

\begin{tabular}{|c|c|c|c|c|}
\hline \multirow{2}{*}{$\begin{array}{l}\text { Time } \\
\text { (hrs) }\end{array}$} & \multicolumn{2}{|c|}{ SSDL broth } & \multicolumn{2}{|c|}{ Mesquite hydrated mash } \\
\hline & Stirring & Static & Stirring & Static \\
\hline 0 & $5.68 \pm 0.05^{\mathrm{Aa}}$ & $5.70 \pm 0.07^{\mathrm{Aa}}$ & $5.72 \pm 0.03^{\mathrm{Aa}}$ & $5.71 \pm 0.03^{\mathrm{Aa}}$ \\
\hline 2 & $5.23 \pm 0.07^{\mathrm{Bb}}$ & $5.97 \pm 0.16^{\mathrm{Aa}}$ & $5.81 \pm 0.02^{\mathrm{Aa}}$ & $5.81 \pm 0.00^{\mathrm{Aa}}$ \\
\hline 4 & $5.82 \pm 0.10^{\mathrm{Aa}}$ & $5.89 \pm 0.20^{\mathrm{Aa}}$ & $5.88 \pm 0.00^{\mathrm{Aa}}$ & $5.95 \pm 0.04^{\mathrm{Aa}}$ \\
\hline 6 & $6.04 \pm 0.07^{\mathrm{Aa}}$ & $5.64 \pm 0.15^{\mathrm{Aa}}$ & $5.93 \pm 0.01^{\mathrm{Aa}}$ & $5.85 \pm 0.02^{\mathrm{Aa}}$ \\
\hline 8 & $6.38 \pm 0.00^{\mathrm{Aa}}$ & $6.26 \pm 0.18^{\mathrm{Aa}}$ & $6.04 \pm 0.07^{\mathrm{Ba}}$ & $5.96 \pm 0.01^{\mathrm{Aa}}$ \\
\hline 10 & $6.42 \pm 0.08^{\mathrm{Ab}}$ & $8.01 \pm 0.02^{\mathrm{Aa}}$ & $6.10 \pm 0.03^{\mathrm{Ba}}$ & $6.11 \pm 0.04^{\mathrm{Ba}}$ \\
\hline 12 & $7.11 \pm 0.16^{\mathrm{Ab}}$ & $8.98 \pm 0.18^{\mathrm{Aa}}$ & $6.10 \pm 0.03^{\mathrm{Ba}}$ & $6.15 \pm 0.08^{\mathrm{Ba}}$ \\
\hline 14 & $7.56 \pm 0.08^{A b}$ & $9.53 \pm 0.09^{\mathrm{Aa}}$ & $6.75 \pm 0.02^{\mathrm{Ba}}$ & $6.94 \pm 0.17^{\mathrm{Ba}}$ \\
\hline 16 & $7.69 \pm 0.00^{A b}$ & $9.66 \pm 0.11^{\mathrm{Aa}}$ & $6.78 \pm 0.03^{\mathrm{Ba}}$ & $6.82 \pm 0.02^{\mathrm{Ba}}$ \\
\hline 18 & $8.05 \pm 0.09^{A b}$ & $9.81 \pm 0.06^{\mathrm{Aa}}$ & $7.07 \pm 0.01^{\mathrm{Ba}}$ & $6.71 \pm 0.03^{\mathrm{Bb}}$ \\
\hline 20 & $8.27 \pm 0.09^{A b}$ & $9.82 \pm 0.08^{\mathrm{Aa}}$ & $7.09 \pm 0.01^{\mathrm{Ba}}$ & $6.79 \pm 0.04^{\mathrm{Bb}}$ \\
\hline 22 & $7.46 \pm 0.08^{A b}$ & $9.83 \pm 0.02^{\mathrm{Aa}}$ & $7.10 \pm 0.06^{\mathrm{Ba}}$ & $6.65 \pm 0.04^{\mathrm{Bb}}$ \\
\hline 24 & $7.85 \pm 0.12^{\mathrm{Ab}}$ & $9.85 \pm 0.03^{\mathrm{Aa}}$ & $7.09 \pm 0.03^{\mathrm{Ba}}$ & $6.62 \pm 0.01^{\mathrm{Bb}}$ \\
\hline
\end{tabular}

Time of fermentation $\left(X_{1}\right)$ and condition of fermentation $\left(X_{3}\right)$ showed a slight influence on the microbial count in the mash (Table 6). There was no clear difference for the counts of S. cerevisiae and Z. mobilis after $18(-1)$ and 36 (1) hrs of cultivation (Figure 1c).

The highest ethanol concentration $\left(141.1 \mathrm{gL}^{-1}\right)$ for the interaction $\mathrm{X}_{1} \cdot \mathrm{X}_{2} \cdot \mathrm{X}_{3}$ was noted in the levels 1 ( $36 \mathrm{hrs),} 1$ (Z. mobilis) and -1 (static cultivation) (Figure 1a). $X_{2} \cdot X_{3}$ (type of microorganism and cultivation condition) was the interaction that most affected the ethanol production (-31.60) (Table 6). Ethanol concentration was higher $\left(132.24 \mathrm{gL}^{-1}\right)$ in the mash inoculated with $Z$. mobilis under static cultivation (Figure 2). It is interesting to cite than even being found high counts of $Z$. mobilis in the mash kept under stirring condition, it did not mean higher ethanol production. 
Tano and Buzzato (2003) noted a low ethanol production $\left(29 \mathrm{gL}^{-1}\right)$ by Z. mobilis in sugar cane juice during $24 \mathrm{hrs}$ of fermentation in stirring condition. Anaerobic cultures of $Z$. mobilis have showed the highest ethanol yields $\left(0.51 \mathrm{~g} \mathrm{glucose}^{-1}\right)$ in different substrates, while small yields $\left(0.13 \mathrm{~g} \mathrm{glucose}^{-1}\right)$ have been noted in aerobic cultures (Kalnenieks et al. 2000; Prasad et al. 2007). Previous studies suggested a possible average yield of ethanol from mesquite pods of up to $260 \mathrm{~L}$ per ton, while for sugar cane it is purposed an average yield of up to $80 \mathrm{~L}$ per ton (Silva et al. 2003, Silva et al. 2007).

Table 6. Analysis of main effects and their interaction in the $2^{3}$ factorial design for ethanol production in mesquite pods hydrated mash.

\begin{tabular}{cccc}
\hline Variables & \multicolumn{3}{c}{ Answers } \\
\cline { 2 - 4 } & $\begin{array}{c}\text { Ethanol } \\
\left(\mathbf{g L}^{-1}\right)\end{array}$ & $\begin{array}{c}\text { Glucose } \\
\left(\mathbf{g L}^{-1}\right)\end{array}$ & $\begin{array}{c}\text { Biomass } \\
\text { (Log cfu } \mathbf{~ m L}^{-1} \text { ) }\end{array}$ \\
Time of fermentation $\left(\mathrm{X}_{1}\right)$ & -4.17 & -5.02 & -0.16 \\
Type of microorganism $\left(\mathrm{X}_{2}\right)$ & 58.28 & 1.24 & $\mathrm{NS}$ \\
Condition of fermentation $\left(\mathrm{X}_{3}\right)$ & -35.65 & -1.46 & 0.45 \\
$\mathrm{X}_{1} \mathrm{X}_{2}$ & $\mathrm{NS}$ & -1.25 & $\mathrm{NS}$ \\
$\mathrm{X}_{1} \mathrm{X}_{3}$ & -11.18 & 1.47 & $\mathrm{NS}$ \\
$\mathrm{X}_{2} \mathrm{X}_{3}$ & -31.60 & 1.49 & -0.16 \\
$\mathrm{X}_{1} \mathrm{X}_{2} \mathrm{X}_{3}$ & -10.72 & -1.50 & -0.20 \\
\hline
\end{tabular}

NS: no significant for $\mathrm{p}<0.05$

However, these values of higher yield of ethanol from mesquite pods could be still analyzed cautiously in respect of the production of each culture. The average production of mesquite pods has been cited to be around 10 tons per hectare of planted tree, while for sugar cane the average production has been of approximately 90 tons per hectare (Rípoli et al. 2000; Maule et al. 2001; Silva et al. 2003). These previous findings suggest a possible average yield of ethanol from mesquite pods and sugar cane of up to 2600 and $7200 \mathrm{~L}$ per hectare of the culture, respectively.

Our results suggest that mesquite pods could be known as an alternative substrate for biotechnological purposes, mainly for ethanol production. Mesquite hydrated mash at

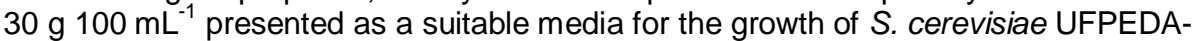
1012 and Z. mobilis UFEPEDA-205 in submerged fermentation. Ethanol yield was found to be higher when $Z$. mobilis UFEPEDA-205 was cultivated in mesquite hydrated mash under static condition.

\section{REFERENCES}

ARAÚJO, Ana H.; CARDOSO, Patricia C.B.; PEREIRA, Railene A.; LIMA, Liziane M.; OLIVEIRA, Adeliana S.; MIRANDA, Maria Raquel A.; XAVIER-FILHO, José and SALES, Maurício P. In vitro digestibility of globulins from cowpea (Vigna unguiculata) and xerophitic algaroba (Prosopis juliflora) seeds by mammalian digestive proteinases: a comparative study. Food Chemistry, August 2002, vol. 78, no. 2, p. 143-147. [CrossRef]

ATIYEH, Hasan and DUVNJAK, Zdravko. Production of fructose and ethanol from sugar beet molasses using Saccharomyces cerevisiae ATCC 36858. Biotechnology Progress, 2002, vol. 18, no. 2, p. 234-239. [CrossRef] 
BATISTA, A.M.; MUSTAFA, A.F.; MCKINNON, J.J. and KERMASHA, S. In situ ruminal and intestinal nutrient digestibilities of mesquite (Prosopis juliflora) pods. Animal Feed Science and Technology, September 2002, vol. 100, no. 1-2, p. 107-112. [CrossRef]

BORSARI, Raquel Renan Jorge; CELLIGOI, Maria Antonia P. Colabone; BUZATO, João Batista and SILVA, Rui S.S.F. da. Influence of carbon source and the fermentation process on levan production by Zymomonas mobilis analyzed by the surface response method. Ciência e Tecnologia de Alimentos, July-September 2006, vol. 26, no. 3. [CrossRef]

BOTHAST, R.J. and SCHLICHER, M.A. Biotechnological process for conversion of corn into ethanol. Applied Microbiology and Biotechnology, April 2005, vol. 67, no. 1, p. 19-25. [CrossRef]

BRAVO, Laura; GRADES, Nora and SAURA-CALIXTO, Fulgencio. Composition and potential uses of mesquite pods (Prosopis pallida L.): Comparison with carob pods (Ceratonia siliqua L.). Journal of the Science of Food and Agriculture, July 1994, vol. 65, no. 3, p. 303-306. [CrossRef]

BRINGER, Stephanie; FINN, Robert K. and SAHM, Hermann. Effect of oxygen on the metabolism of Zymomonas mobilis. Archives of Microbiology, November 1984, vol. 139, no. 4, p. 376-381. [CrossRef]

CARVALHO, Giovani Brandão Mafra de; ROSSI, Adriana Andréia and SILVA, João Batista de Almeida e. Elementos biotecnológicos fundamentais no processo cervejeiro: $2^{\mathrm{a}}$. parte - A fermentação. Revista Analytica, Dezembro 2006-Janeiro 2007, no. 26, p. 46-54.

DATAR, Rohit P.; SHENKMAN, Rustin M.; CATENI, Bruno G.; HUHNKE, Raymond L. and LEWIS, Randy S. Fermentation of biomass-generated producer gas to ethanol. Biotechnology and Bioengineering, June 2004, vol. 86, no. 5, p. 587-594. [CrossRef]

DEANS, J.D.; DIAGNE, O.; NIZINSKI, J.; LINDLEY, D.K.; SECK, M.; INGLEBY, K. and MUNRO, R.C. Comparative growth, biomass production, nutrient use and soil amelioration by nitrogen-fixing tree species in semi-arid Senegal. Forest Ecology and Management, March 2003, vol. 176, no. 1-3, p. 253-264. [CrossRef]

FAVELA TORRES, E. and BARATTI, J. Ethanol production from wheat flour by Zymomonas mobilis. Journal of Fermentation and Technology, 1988, vol. 66, no. 2, p. 167-172. [CrossRef]

GRAY, Kevin A.; ZHAO, Lishan and EMPTAGE, Mark. Bioethanol. Current Opinion in Chemical Biology, April 2006, vol. 10, no. 2, p. 141-146. [CrossRef]

INSTITUTO ADOLFO LUTZ (IAL). Métodos Físico-químicos para Análises de Alimentos. $4^{\mathrm{a} .}$ ed. Brasília, National Agency for Health Surveillance, 2005. 1020 p.

JOACHIMSTHAL, Eva; HAGGETT, Kevin D.; JANG, Jin-Ho and ROGERS, Peter L. A mutant of Zymomonas mobilis ZM4 capable of ethanol production from glucose in the presence of high acetate concentrations. Biotechnology Letters, February 1998, vol. 20, no. 2, p. 137142. [CrossRef]

KAILAPPAN, R.; GOTHANDAPANI, L. and VISWANATHAN, R. Production of activated carbon from prosopis (Prosopis juliflora). Bioresource Technology, December 2000, vol. 75, no. 3, p. 241-243. [CrossRef]

KALNENIEKS, Uldis; GALININA, Nina; TOMA, Malda M. and POOLE, Robert K. Cyanide inhibits respiration yet stimulates aerobic growth of Zymomonas mobilis. Microbiology, June 2000, vol. 146, no. 6, p. 1259-1266.

MAHGOUB, Osman; KADIM, Isam T.; FORSBERG, Neil E.; AL-AJMI, Dawood S.; AL-SAQRY, Naseeb M.; AL-ABRI, Abdullah S. and ANNAMALAI, Kanthi. Evaluation of meskit (Prosopis juliflora) pods as feed goats. Animal Feed Science and Technology, June 2005, vol. 121, no. 3-4, p. 319-327. [CrossRef]

MAULE, Rodrigo Fernando; MAZZA, Jairo Antonio and MARTHA JR., Geraldo Bueno. Produtividade agrícola de cultivares de cana-de-açúcar em diferentes solos e épocas de colheita. Scientia Agricola, April-June 2001, vol. 58, no. 2, p. 295-301. [CrossRef]

McLELLAN, P. James; DAUGULIS, Andrew J. and LI, Jinghong. The incidence of oscillatory behavior in the continuous fermentation of Zymomonas mobilis. Biotechnology Progress, 1999, vol. 15, no. 4, p. 667-680. [CrossRef]

MIELENZ, Jonathan R. Ethanol production from biomass: technology and commercialization status. Current Opinion in Microbiology, June 2001, vol. 4, no. 3, p. 324-329. [CrossRef]

MONTESINOS, Thierry and NAVARRO, Jean-Marie. Production of alcohol from raw wheat flour by amyloglucosidase and Saccharomyces cerevisiae. Enzyme and Microbial Technology, September 2000, vol. 27, no. 6, p. 362-370. [CrossRef] 
NARENDRANATH, Neelakantam V. and POWER, Ronan. Effect of yeast inoculation rate on the metabolism of contaminating lactobacilli during fermentation of corn mash. Journal of Industrial Microbiology \& Biotechnology, December 2004, vol. 31, no. 12, p. 581-584. [CrossRef]

O'BRIEN, R.W. and MORRIS, J.G. Oxygen and the growth and metabolism of Clostridium acetobutylicum. Journal of General Microbiology, November 1971, vol. 68, no. 3, p. 307318. [CrossRef]

PALMAROLA-ADRADOS, Beatriz; CHOTĚBORSKÁ, Pavla; GALBE, Mats and ZACCH I, Guido. Ethanol production from non-starch carbohydrates of wheat bran. Bioresource Technology, May 2005, vol. 96, no. 7, p. 843-850. [CrossRef]

PRASAD, S.; SINGH, A. and JOSHI, H.C. Ethanol as an alternative fuel from agricultural, industrial and urban residues. Resources, Conservation and Recycling, March 2007, vol. 50, no. 1, p. 1-39. [CrossRef]

RÍPOLI, Tomaz Caetano Cannavam; MOLINA JR., Walter Francisco and RÍPOLI, Marco Lorenzzo Cunali. Energy potential of sugar cane biomass in Brazil. Scientia Agricola, October-December 2000, vol. 57, no. 4. [CrossRef]

RIVEROS, F. The genus Prosopis and its potential to improve livestock production in arid and semi arid regions. In: SPEEDY, A. and PUGLIESE, P. eds. Legume Trees and Other Fodder Trees as Protein Sources for Livestock. Roma, FAO, 1992. p. 257-276.

ROSILLO-CALLE, Frank and CORTEZ, Luis A.B. Towards ProAlcohol II - a review of the Brazilian Bioethanol Programme. Biomass and Bioenergy, March 1998, vol. 14, no. 2, p. 115-124. [CrossRef]

SHENE, C. and BRAVO, S. Zymomonas mobilis CP4 fed-batch fermentations of glucosefructose mixtures to ethanol and sorbitol. Applied Microbiology and Biotechnology, October 2001, vol. 57, no. 3, p. 323-328. [CrossRef]

SILVA, Clovis Gouveia; MATA, Mario Eduardo R.M. Cavalcanti; BRAGA, Maria Elita Duarte and QUEIROZ, Vital de Sousa. Extração e fermentação do caldo de algaroba (Prosopis juliflora (Sw) D.C.) para obtenção de aguardente. Revista Brasileira de Produtos Agroindustriais, 2003, vol. 5, no. 1, p. 51-56.

SILVA, Celiane Gomez Maia da; MELO FILHO, Artur Bibiano; PIRES, Edleide Freitas and STAMFORD, Tânia Lúcia Montenegro. Caracterização físico-química e microbiológica da farinha de algaroba (Prosopis juliflora (Sw.) DC). Ciência e Tecnologia de Alimentos, October-December 2007, vol. 27, no. 4. [CrossRef]

SWINGS, J. and DE LEY, J. The biology of Zymomonas. Bacteriological Review, March 1977, vol. 41 , no. 1 , p. 1-46.

TABOSA, I.M.; SOUZA, J.C.; GRAÇA, D.L.; BARBOSA FILHO, J.M.; ALMEIDA, R.N. and RIETCORREA, F. Neuronal vacuolation of the trigeminal nuclei in goats caused by ingestion of Prosopis juliflora pods (mesquite beans). Veterinary and Human Toxicology, June 2000, vol. 42, no. 3, p. 155-158.

TANO, Marcia Sadae and BUZATO, João Batista. Effect of the presence of initial ethanol production in sugar cane juice fermented by Zymomonas mobilis. Brazilian Journal of Microbiology, July-September 2003, vol. 34, no. 3, p. 242-244. [CrossRef]

\section{How to cite this article:}

SILVA, C.G.; STAMFORD T.L.; de ANDRADE, S. A.; de SOUZA. E. and de ARAÚJO, J. Production of ethanol from mesquite (Prosopis juliflora (SW) D.C.) pods mash by Zymomonas mobilis and Saccharomyces cerevisiae. Electronic Journal of Biotechnology, September 2010, vol. 13, no. 5. http://dx.doi.org/10.2225/vol13-issue5-fulltext-21 